\title{
Strategic Positioning of Archives in Disaster Recovery Procedures
}

TIM HARRIS, PH.D.

Head of Access and Buildings in the Department of Culture, Heritage and Libraries of the City of London, London Metropolitan Archives, 40 Northampton Road, London EC1R 0HB, United Kingdom

e-mail: Tim.Harris@cityoflondon.gov.uk

\author{
Strategic Positioning of Archives in Disaster Recovery Procedures
}

\begin{abstract}
This paper will show that by positioning itself as a centre of excellence for emergency planning and disaster recovery, London Metropolitan Archives (LMA) has established itself as a key player for the City of London. LMA could demonstrate it already had detailed emergency plans and disaster recovery plans in place which meant it was ahead of other parts of the organisation. The archive reference room resembled very closely a disaster recovery centre. Discussions enabled the vision of a disaster recovery centre to be located in the archive building at LMA. The paper will look at the ways in which this has provided challenges in space planning and technological infrastructure but its reputation as a provider of excellent public services has enabled it to be a very valuable participant in wider security and emergency planning initiatives.
\end{abstract}

Key words: disaster recover, emergency planning, London Metropolitan Archives, space planning, technological infrastructure

Il posizionamento strategico degli archivi nelle procedure di recupero dalle calamità

\section{SINTESI}

Il presente articolo dimostrerà che, posizionandosi come un centro di eccellenza per la pianificazione e ripristino di emergenza, il London Metropolitan Archives (LMA) si è affermato come un elemento chiave per la città di Londra. LMA ha potuto dimostrare che già aveva dettagliati piani di emergenza e piani di disaster recovery in loco che significavano che era avanti ad altri settori dell'organizzazione. La reference room dell'archivio ricordava molto da vicino un centro di recupero di disastro. Le discussioni in merito hanno portato alla visione di un centro di recupero dalle calamità localizzato nell'edificio del LMA. L'articolo esaminerà i modi in cui ciò ha costituito una sfida riguardo l'infrastruttura tecnologica e la pianificazione spaziale, ma la sua reputazione come fornitore di servizi pubblici eccellenti gli ha consentito di partecipare efficacemente alla più ampia sicurezza ed alle iniziative di pianificazione d'emergenza.

Parole chiave: risposta alle catastrofi di vasta portata, pianificazione di emergenza, Archivio Metropolitano Londinese, pianificazione degli spazi, infrastrutture tecnologiche

Strateška umestitev arhiva v postopkih reševanja v primeru nesreč

\section{IZVLE $\check{C} E K$}

V članku bo avtor pokazal, da se je Londonski metropolitanski arhiv (LMA) s tem, ko si je pridobil sloves centra odličnosti za načrtovanje $\mathrm{v}$ izrednih razmerah in nesrečah, uveljavil kot ključni akter za mesto London. LMA je dokazal, da je že imel podrobne načrte za izredne razmere in načrt za postopke reševanja, kar je pomenilo, da je bil daleč pred drugimi. Soba za konzultacije je namreč zelo podobna centru za izredne razmere in razprave so omogočile vizijo vzpostavitve centra za izredne razmere v zgradbi arhiva LMA. Prispevek se bo osredotočil na izzive pri načrtovanju prostorov in tehnološko infrastrukturo. Njegov ugled, kot ponudnik odličnih javnih storitev mu je omogočil, da je postal zelo dragocen udeleženec v načrtovanja širših varnostnih pobud.

Ključne besede: postopki reševanja, varnostno načrtovanje sili, Londonski metropolitanski arhiv, urejanja prostora, tehnološka infrastruktura 


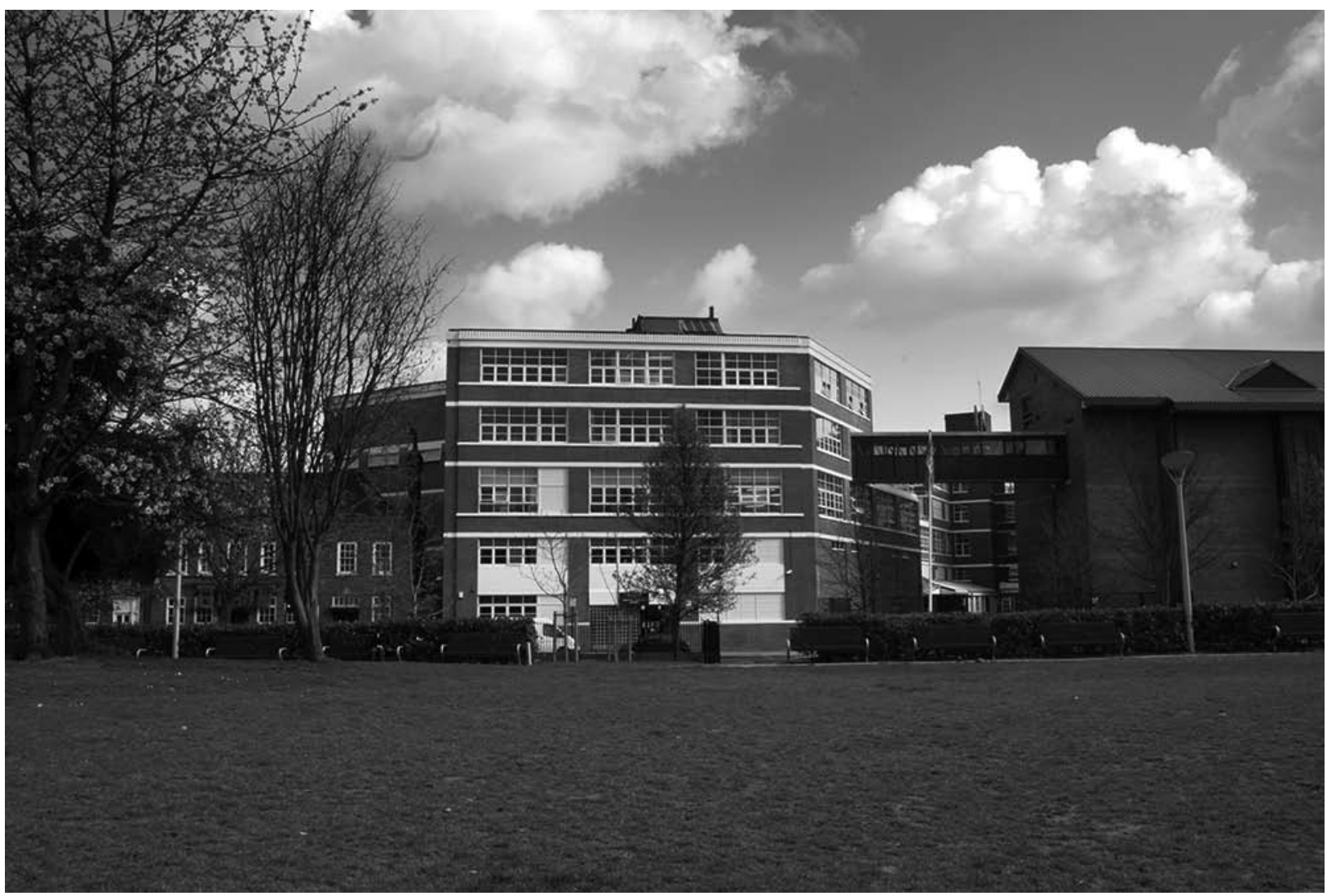

Figure 1: London Metropolitan Archives

London Metropolitan Archives (LMA) is the largest local authority managed archive in the United Kingdom with over $100 \mathrm{~km}$ of contents on shelving in Central London. The archives consist of the magnificent City of London Corporation archive dating from 1067 - date; the manuscripts of the Guildhall Library; and the Metropolitan collections of the counties of London, Middlesex and the former Greater London Council. It has a habit of reinventing itself as local government structures change but is now mostly centred on one set of premises in Clerkenwell, just outside the ancient city walls. In each year it receives 30,000 onsite visitors, 25,000 distance enquiries and 30 million web page hits.

LMA and its predecessors were early adopters of Disaster Planning and have been long-standing customers of Harwell Document Restoration Services since 1980. Association with an organisation like Harwell (set in a nuclear facility near Oxford) has provided a major building block for the strategic positioning of archives in disaster recovery procedures for LMA as part of the City of London. It is LMA who administer (and pay for) the contract with Harwell on behalf of the City authorities which means the archives are already in a position of power with regard to decision making on disaster recovery.

Harwell, since its inception in 1979, has provided services to insurers, loss adjusters, damage management companies, Information Technology specialists and archivists, museum curators and archaeologists after losses in commercial and local authority premises. It houses Europe's largest dedicated facilities and capacity dedicated to document and book recovery - especially from water and fire-damage. Its swift response ensures a minimal impact due to secondary damage or unnecessary business disruption. Freeze drying technology has enabled archivists to be confident about document recovery (especially in buildings fitted with wet pipe sprinklers beloved of insurance companies). They now have over 800 large organisations who retain them for their document restoration needs and operate to industry standards under ISO 9001:2000. Their training is very practical and of a high standard which can be tailored according to the client's needs. 
In 2005 the City authorities were planning to reconfigure their central London headquarters at the Guildhall and many different options were put to them for the solution to the change in administrative requirements from a building which had not changed much since the 1950s (albeit one designed by a very famous architect Sir Giles Gilbert Scott) It was clear that for the modern city to look and act as if it belonged in the Twenty First Century it needed to operate from premises that reflected its desire to do business with the modern financial City and its stakeholders.

One of the options tabled was for Modern Records Management to be implemented as never before so as to reduce storage and desk capacity at Guildhall. A Records Management survey was commissioned which was undertaken by LMA at the same time as a future space allocation survey was done by the building consultants predicting future office space needs. The resulting strand in the overall Guildhall Improvement Project was labelled EP2, Enabling Project 2, Archives and Records Management. Again it was the relatively small City archive service, LMA (with 100 staff), which was providing the enabling for the larger organisation (with 3500 staff) to reach its greater objectives the improvement of its public service.

The existing building at London Metropolitan Archives could not accommodate the estimated additional storage for $10 \mathrm{~km}$ of Records Management boxes from City of London departments. A business case had to be made to demonstrate that future plans for LMA would be able to accommodate the Records Management requirement and in return the LMA would receive new shelving and any surplus capacity it could engineer within the site. A bold plan to reconfigure the ground floor of the LMA's Clerkenwell site resulted in an additional $17 \mathrm{~km}$ of space being found by a process of resetting shelf direction and extending the height of the shelves to $4.5 \mathrm{~m}$. This capacity was found within the existing building envelope through close consultation of engineers, shelf planners and City archivists.

In addition to the physical requirements of storage there was the accompanying need to provide a retrieval service to the existing administrative organisation. New service level agreements were established with departments which meant that small quantities of files could be recalled twice a day with a four hour service, which were sent over in a dedicated Records Management van with fully trained staff, knowledgeable in document handling. An alternative option was given for larger quantities to be viewed at LMA in the public Archive Study Area (or if confidential in a pre-booked closed room).

Operating as The City of London Records Management Service (CRMS for short) the service became a popular and much-trusted part of everyday life for the departments of the City. This enabled LMA to raise its profile and suddenly it was being consulted on all manner of internal policies and strategic planning in a way that was not possible when it was just an archive service. Chief Officers of the City recognised the quality and efficiency of the service and became more open to talking about their records and how best to store them for the future. For the first time a lot of the City's modern records were properly boxed and packaged which in itself was a huge step forward for preservation (and inter alia for future disaster recovery and emergency planning).

With the change in focus brought about by a 16\% reduction in budgets in 2011 the City was looking to rethink the way it provided certain services. One such service was emergency planning and disaster recovery. Since the 1980s the City had paid a retainer to a major international business firm to host a disaster recovery suite in a different part of London in case there was a major disaster either at, or in the vicinity of, the City's administrative headquarters. The concept had remained the same, namely a provision of a suite of personal computers on desks with provision for desktop printing and basic recovery services to maintain an administrative presence through a temporary crisis period.

Approaches were made to LMA (and other organisations run by the City) to see if there were any possible alternative locations where a similar service could be provided. The rows of 48 computers in the LMA's main reference area, the Information Area, was very appealing to the emergency planners. Equally the large flexible Archive Study Area provided excellent space for the use of laptops for another 50 members of an essential Business Continuity Team. Together with multiple meeting room spaces LMA could offer enough facilities for the parent organisation to get itself back on its feet after a disaster affecting its main headquarters.

The idea was fine in theory, but would it work in practice? A number of test events were held to ensure key staff had familiarity with the LMA building's public areas. It was demonstrated that the 
Information Technology specialists could operate the main City network of essential activities from the same terminals as the existing ones used by the archives to provide access to its catalogue and digitised collections, used on a daily basis by onsite visitors to LMA. This meant that a disaster recovery centre could be established at LMA within a matter of hours, enabling the City to continue with its everyday business of administering the City of London and supporting its residents and businesses. By contrast onsite public access to the archives would need to be temporarily suspended but archive staff would continue to work on cataloguing, digitisation and conservation as usual in the non-public areas of LMA.

Within the City of London there is a structure for managing Business Continuity and Emergency Planning. Its importance is recognised in the fact that it is based within the Chief Executive's own department. The City of London Contingency Planning Team works alongside the Police to provide joint training to make the City more resilient in the face of disasters and disruptions. A number of familiarisation sessions have been held for leading members of City departments which have again raised the profile of the archive service. Departments can store specialist equipment or resources as would be required in the event of an emergency. This same principle has been extended by the Police who now use the LMA car park to store one of their disaster response vehicles which would be taken to the scene of a Major Incident and is kitted out ready for instant use.

The Disaster Plan for LMA covers 4 Grades of Emergency: Minor, Moderate, Major and Catastrophic and the responses available in each different type. The main storage areas are identified with a brief resume of type of documents stored and shelving type (there are over 30 different storage areas each with different characteristics. A list of relevant emergency equipment and location is given- anything from wellington boots to freezer bags. Management roles and responsibilities are defined so that the process is clear: if the plan is to be invoked by the management team it results in the formation of a Business Continuity Planning team who control response to a major event; later in the process the work is passed to a Business Recovery Team who coordinate a plan of action to put things back together again.

The recovery procedure is outlined in detail in a number of Appendices at the end of this paper. These provide information on the essential steps to be taken after any disaster, a consistent methodology for detailed record keeping, and guidelines on what techniques to use in different circumstances according to the type of damage and the materials involved ( 22 different materials are identified anything from seals to vinyl records). For ease of use templates to record movements of items or Incident Record sheets are kept ready for instant duplication so information is recorded in a structured and consistent format. Regular disaster response exercises and continued training has enabled staff to approach possible disaster scenarios with increased confidence.

The local LMA Emergency Planning and Recovery manual ties in with the City of London's main Business Continuity Plan but it is considered highly unlikely that both sites would be unavailable in the event of a major emergency. A recent Business Impact Analysis investigated the risk level and found them to be low.

This paper has shown that it is possible for archive services to provide services to its governing institution in innovative and perhaps unusual ways. The well-established disaster planning regime demonstrated an early commitment to best practice which, coupled with a growing reputation for delivering excellent records management services, gave the archive service the opportunity to influence disaster recovery policy at a strategic level within the organisation. The opportunity was seized and has meant a much raised profile and better infrastructure support for London Metropolitan Archives as a key player within the City of London. 


\section{Appendix 1}

\section{Extract from LMA Emergency Planning and Recovery Manual}

\section{Policy Statement}

\subsection{Emergency Planning and Recovery}

LMA recognises that advance planning, training and up-to-date reaction plans are crucial to an effective response to a fire, flood or other emergency situation. LMA has an up-to-date Fire \& Evacuation Procedure, and is included in the Culture, Heritage and Libraries (CHL) Business Continuity Plan. Two copies of a confidential Managers Emergency Pack are provided to the senior management team, one copy of which is kept at home. These documents, together with the Emergency Planning and Recovery Manual, include detailed information on salvage techniques, emergency equipment, plans of the building, response procedures for minor \& major incidents and a list of contacts and suppliers. The City of London, and therefore LMA, is a Priority User Plus with Harwell Drying and Restoration service.

The aim of the Emergency Planning and Recovery Manual is to provide a checklist of information relating to response measures. It outlines how LMA staff should act in response to both minor and major incidents. The manual contains the following sections:

1. Details the purpose and coverage of the manual

2. Identifies the 4 incident grades and contents of emergency directives

3. Details relevant information from the City of London Emergency Management document

4. Outlines the location of material and identifies general storage areas

5. Describes LMA procedures in the event of a minor or moderate incident

6. Describes LMA procedures in the event of a major or catastrophic incident

7. Provides information on the various procedures leading up to actual salvage

8. Details salvage techniques for a range of archive material

9. Provides examples and procedures for documentation

10. Lists names and contact numbers for suppliers, conservation and salvage advice

\section{Appendix 2}

\section{Extract from LMA Emergency Planning and Recovery Manual}

5 First Procedures for Minor \& Moderate Incidents

\subsection{All Staff - Order of Operations}

ALERT SENIOR STAFF - All LMA staff

CHECK WHETHER THE INCIDENT AREA IS SAFE - Buildings Services

CHECK THE CAUSE \& SCALE OF THE PROBLEM - Senior Staff and Buildings Services

COLLECT EMERGENCY EQUIPMENT - Appointed Staff and Conservation

PROTECT UNDAMAGED MATERIAL - Appointed Staff and Conservation

ASSESS DAMAGE AND PRIORITISE ACTION - Senior Staff and Conservation

IF NECESSARY, BUSINESS RECOVERY TEAMS WILL BE APPOINTED.

Senior Staff and Conservation

MOVE ALL WET MATERIAL TO A MEETING ROOM FOR SORTING

- Appointed Staff and Conservation \& Appendix A.3 Removal

SECURE AND STABILISE INCIDENT AREA - Buildings Services \& Appendix A.2 Stabilising

CLEAR UP INCIDENT AREA - Buildings Services 


\subsection{Assessment of Incident}

Consider the following when assessing an incident -

- Room number and where in the room;

- Check the rooms below an incident, water travels rapidly down walls and columns;

- The exact number of shelves or bays affected;

- The source of the problem e.g. a leaking pipe, toilet or ground water flood;

- Try to estimate whether the water is clean or dirty without coming into contact with it;

- Indicate whether mould is present or not;

- When the problem occurred e.g. a leaking pipe that has just been discovered, or a flood, due to heavy rain - estimate whether material had been wet for over 24 hours or not;

- What type of material is affected, i.e. books, prints, rolled plans, parchment, photographs

- Whether it is boxed or unboxed, framed or unframed;

- How wet material is e.g. just damp because the leak has just splattered over a shelf of books, or completely soaked because a burst pipe has poured water directly into them;

- Whether the impact is variable e.g. some material is just damp and some completely wet list roughly how many shelves of each type;

- Where the items have been affected e.g. the shelf itself is soaked so the books are wet all along their lower edges, or they are wet through all at one corner;

- Ensure all unaffected areas are protected and that adjacent undamaged material is removed or protected quickly and carefully;

- Remove all debris and excess water;

- Package wet material before moving, see A.3 Removal from Incident Area.

\section{SUMMARY}

This paper will show that by positioning itself as a centre of excellence for emergency planning and disaster recovery, London Metropolitan Archives (LMA) has established itself as a key player within disaster recovery for the whole administration of the City of London at the heart of the capital of the United Kingdom. By taking on Records Management for the City of London, LMA had already built up a reputation for efficient service to constituent departments of the local government organisation, on top of its role as managing a very fine historic city archive. Because it was running such a key service to underpin the governance of the City, the LMA were included at the very early planning stages of new strategies for emergency planning, disaster recovery and business continuity. LMA could demonstrate it already had detailed emergency plans and disaster recovery plans in place which meant it was ahead of other parts of the organisation and had experience of managing salvage contracts with external providers. By definition the archive reference room resembled very closely the concept of layered ranks of computers and desks which business leaders were used to as the format of a disaster recovery centre. Discussions with Information Technology support and partnership with other related organisations enabled the vision of a disaster recovery centre to be located actually in the archive building at LMA. The paper will look at the ways in which this has provided challenges in space planning and technological infrastructure but also political and physical benefits for the archive service. On balance the advantages of working alongside the administrative organisation to find a solution to the very real emergency planning issues at the centre of a very large international city has been very advantageous to the LMA and its reputation as a provider of excellent public services has enabled it to be a very valuable participant in wider security and emergency planning initiatives. The methodology of the Emergency Planning and Recovery Manual will be highlighted alongside practical ways in which the Disaster Recovery programme has been developed. It is a useful case study of how archive expertise can be used in very different ways to further the ends of the archive.

Typology: 1.04 Professional Article

Submitting date: 05.03.2015

Acceptance date: 09.04.2015 